\title{
Crow Songs (Vraní zpěvy)
}

Author: Radek Malý

First Published: 2002

About the Author: Radek Malý (1977) studied Czech and German at the Palacký University in Olomouc. Apart from teaching at the university and researching translatological tasks (e.g. two monographs reflecting Czech reading of Georg Trakl's and Paul Celan's work), he translates from the German (especially expressionistic poets) and is an editor of many anthologies of poems as well as the Czech anthology of German expressionistic poets. Although Radek Malý is also the author of plays or fairy tales, representative part of his fictional production is based on poetry.

Further Important Publications: Lunovis (2001, Lunovis; poems); Větrní. Zcestné verše (2005, Poems on the Road; poems); Malá tma (2008; Little Darkness; poems); Pocit nočního vlaku (2008, The Feeling of a Night Train; broadcasted also as a radio drama); Světloplaši (2012, The Light Shy; poems); Domovem v jazyce: České čtení Paula Celana. (2012, Resided in the Language: Reading Paul Celan in Czech); V̌̌ehomír (2015, Universe; poems); Franz Kafka - Člověk své a naši doby (2017; Franz Kafka - A Man of His Time and Our Own; essay, in Czech, German and English versions).

\section{Content and Interpretation}

Extraordinary position of Radek Malýs poetry in the context of fiction about the Shoah is tied, besides other things, with the frequency of such motifs. At least one Shoah motif is present in every collection of his poems. This theme appears also in his short play The Feeling of a Night Train, naturally in his academic book about Celan, translations and anthologies of Jewish authors (e.g. Czech German Hugo Sonnenschein, Vlastimil Artur Polák-Avalos).

In his second collection of poems Crow Songs, there are several motifs of Shoah too. The poem Buchenwald, 28. 11. 2000, in which he combined Czech high standard metric style dactyl (rhyme: ab-ab), colloquial language and fatal absurd grotesque (rk, 2014).

Prolapsed November

Drizzling gently down from grey clouds

A day perhaps only good enough

to visit a concentration camp

You got up early after a binge

You see it in a non-conform way:

A hundred skeletons dressed in pyjamas

A few gods in uniforms

Ә Open Access. () 2021 Štěpán Balík, published by De Gruyter. (cc) BY-NC-ND This work is licensed under a Creative Commons Attribution-NonCommercial-NoDerivatives 4.0 License. 
(Technical subject translation by Alexandra Šípová, also in other fragments of Malý's poems.) (Malý, 2002, p. 34).

This poem is preceded by another two texts of this kind: iambic Jedem das Seine (To Each His Own; a motto displayed over the entrance of Buchenwald concentration camp) and trochaic Es ist mir trotzdem kalt (Nevertheless, I'm Cold). In the first one, Malý - fascinated by folk songs and nursery rhymes - elaborates two slogans, the first one from the gate in the Buchenwald camp, the other from Auschwitz. He creates an inappropriate absurd connection between the form with nursery rhymes and the Nazi propaganda sense hidden in defenceless words. Misusing the misused words Malý shifts the language back to its original basic meaning (Latin: suum cuique) (Balik, 2015, p. 237).

ARBEIT MACHT FREI.

Ayay.

Ayayay.

(p. 32)

In the following poem Es ist mir trotzdem kalt, Buchenwald and Auschwitz appear explicitly. The structure of a pun is apparent in this text. However, fatal grotesque is elaborated by rhyming Osvětim (Auschwitz) with the verb posvětim (I will consecrate) and misusing the ambiguity of the phrase step on the gas (přidej plyn) (p. 33). See Borowski's This Way to the Gas, Ladies and Gentlemen $\rightarrow$ Pożegnanie $z$ Maria and Piwowarski's $\rightarrow$ More Gas, Comrades! For Malý's poetry in general, it is significant that the Shoah is presented in the context of Germany, Sudetenland and Czech-German relations. The macaronic German-Czech verses, which appear in his texts very often, refer to this aspect as well as to the former partial bilinguality in the Czech lands. All three poems dedicated to the Shoah here are included in the part with an odd title. It questions the German moral condition by putting together two contrasting texts: the wellknown and very emotional inscription from Auschwitz and a traditional neutral name for a collection of poems: Arbeit macht frei. básně $z$ Němec (Arbeit macht frei. poems from Germany)” (Balík, 2015, p. 238).

\section{Main Topics and Problems}

In general, there are two sources of Malý's inspiration. Firstly, his poetry is influenced by German (Georg Trakl, Georg Heym) and Czech expressionistic poetry (Bohuslav Reynek). One can find - aside from natural motifs - distinctive elements of eschatology and the grotesque.

Secondly, he is also inspired by work of two poets coming out from the former Jewish Austrian-Hungarian region Czernowitz (today in Ukraine) and thematising the Shoah in their poems, Rosa Ausländer and Paul Celan.

Consequently, Malý mentioned also Vlastimil Artur Polák-Avalos, who lived in the same Moravian town Olomouc as Malý has been, and especially his taciturn poem 
Ost-Transport (written 1944/1945, Transport to the East), of which he proposed the new translation (cf. Malý, 2014a, pp. 99-101). Whereas Celan and Polák wrote in German, their mother tongue, but also the language spoken by the murders of his relatives and friends (cf. Baer, 2002, p. 60), Malý writing in Czech (even though with macaronic elements) choses the language of the bystanders, who were present in the time of the destruction of their Jewish and then German neighbours' world, but they did nothing to save it.

In this context, it should be understood regarding the verses where the general "labels" of the Shoah (Auschwitz, well known Nazi slogans, gas etc.) are mentioned, Malý uses these constant representations unusually in order to shock the reader and to force him/her to perceive these untouchable taboo symbols anew (Balík, 2015, p. 235). The rhymes words Faust - Holocaust or Mengele - zbabělé (adjective "coward") are very striking especially in the context of his formally refined poetry. However, this kind of grotesque "misusing" of Holocaust cliché (also with the image of Auschwitz doctor Mengele) is not the unique in Czech literature. It can also be found in Arnošt Goldflam's play $\rightarrow$ At Home with the Hitlers or even in the 1960s in J. R. Pick's poems (Balik, 2017, p. 38). Shocking combination of simple childish form and the Shoah content was already deliberately used - as one of the first probably - by the Polish Warsaw Ghetto poet Władysław Szlengel in poem The Small Station Treblinki. However, in the poetry hic et nunc, the motivation is rather different (cf. Balík, 2014, pp. 49-62). Szlengel $\rightarrow$ Selected Poetry.

A question considering the appropriateness of Malý's treatment of the Shoah seems to be very important. However, a polemic which arose about this issue in Czech Jewish public forums revealed a possible misunderstanding of his specific poetic language. In 2013, a public debate about the sense of one of his poems overlapped the literary discourse after the Cermat office chose Radek Malý's poem Buchenwald, 28. 11.2000 as a part of the "maturita” Exam (the Czech equivalent of the British A-levels), without the author being informed (Balík, 2015, p. 229).

Some authorities from Czech Jewish community argued that such a choice in the context of the Maturita questions had relativised the suffering of the Shoah victims and offended the Czech Jews who lost their relatives during World War II, mainly in the last two verses: "You're half a Jew / and half an SS man” (,Je v tobě Žida půl / a půlka esesáka“). Radek Malý stated he had not relativised Jewish suffering during World War II. He added that the proclamation of Jewish representatives was based on the confusion of the person of the author, his work and the manner in which his work has been treated in public (Malý, 2014b).

Also according to Holý (2013) and Balík (2015, p. 231), these provocative poems has been misinterpreted. Radek Malýs work gives clear evidence about his artistic and moral values. 


\section{Cited Works}

Baer, U. (2002). Celan, Paul. In: T. Riggs, ed., Reference Guide to Holocaust Literature. Detroit: St. James Press, pp. 59-61. Balík, Š. (2014). Ewangelia o Treblince według Glazara, Rajchmana, Wiernika, Willenberga. In: G. Gazda et al., eds., Reprezentacje Shoah $w$ literaturze i filme $w$ Europie Srodkowej: lata powojenne. Acta Universitatis Lodziensis. Folia Scientiae Artium et Litterarum, (11), pp. 49-62. Balík, Š. (2015). The Provocative Poetry of Radek Malý as a Tool for Dealing Appropriately with the Shoah. In: J. Holý, ed., Aspects of Genres in the Holocaust Literatures in Central Europe. Praha: Akropolis, pp. 229-246. Balík, Š., Holý, J. (2016). Mezi tichem a křikem: Poezie o šoa. In: J. Holý, ed., Cizí i blizcí. Židé, literatura, kultura v českých zemích ve 20. století. Praha: Akropolis, pp. 431-520. Balík, Š. (2017). Yelling into the Silence and its Echos: Czech Shoah Poetry Written till 1960s and its Reception. Poznańskie Studia Slawistyczne, (12), pp. 29-45. Holý, J. (2013). Pozoruhodná kniha Lukáše Přibyla a Michala Plzáka. Listy, 43 (6). Available at: http://www.listy.cz/archiv.php?cislo=136\&clanek= 061330 [Accessed: 26.04.2019]. Malý, R. (2002). Vraní zpěry. Brno: Petrov. Malý, R. (2005). Větrní: Zcestné verše. Brno: Petrov. Malý, R. (2014a). Přběhy básní a jejich překladů. Olomouc: Univerzita Palackého. Malý, R. (2014b). Available at: http://radekmaly.flexum.cz/?cs/ [Accessed: 22.08.2014]. rk (=Kopáč, R.). (2014). Radek Malý (Archived profile). In: Czech Literature Portal [online] Available at: http://www.czechlit. cz/en/authors/maly-radek/author.profil/ [Accessed: 14.09.2014].

\section{Further References}

Munk, J., Papoušek, P. and Pavlát, L. (2013). Protest - CERMAT (17/05/2013). [online] Available at: http://www.fzo.cz/2058/protest-cermat/ [Accessed: 26.04.2019]. TJ (2013). Spor o báseň a o zdravý rozum. Židovské listy - redakční blog (9th June of 2013 at 23:30). Available at: http://zidovskelisty.blog.cz/1306/spor-o-basen-a-o-zdravy-rozum [Accessed: 26.04.2019]. 